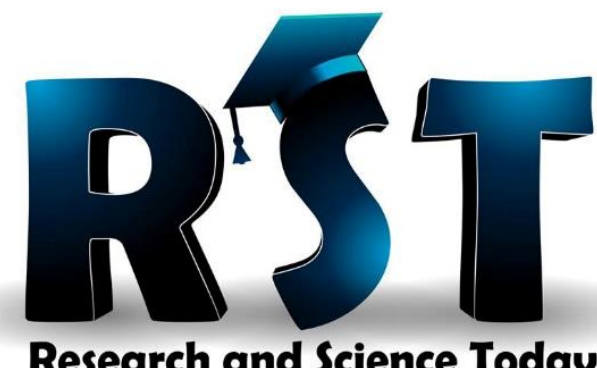

DOI:10.38173/RST.2020.20.2.3:25-39

Title:

EUROPEAN CITIES FACING THE MIGRATION

Author:

Mihaela BOC

Section: INTERNATIONAL RELATIONS

Issue: $\quad 2(20) / 2020$

Received: 1 September 2020

Accepted: 1 November 2020
Revised: -

Available Online: 15 November 2020

Paper available online $\underline{\text { HERE }}$ 


\title{
EUROPEAN CITIES FACING THE MIGRATION
}

Mihaela BOC ${ }^{1}$

\begin{abstract}
:
THE MIGRATION PHENOMENON REPRESENTS A MAJOR CHALLENGE THAT THE EUROPEAN UNION MUST FACE NOWADAYS. THIS IS NOT A NEW ISSUE IN THE HISTORY OF THE EUROPEAN UNION, BUT IT IS CERTAINLY BECOMING MORE AND MORE COMPLEX.

BEFORE BEING A STATE ISSUE, MIGRATION IS A MATTER THAT PRIMARILY CONCERNS HOST CITIES. THE LOCAL ADMINISTRATIONS ARE THE FIRST ONES TO FACE THE PROBLEMS RAISED BY THE INCOMING IMMIGRANTS. THEY ARE THE ONES TO TAKE THE FIRST MEASURES IN ORDER TO HELP THE PEOPLE ENTERING THEIR TERRITORY AND TO MANAGE THE SITUATION THAT THIS PHENOMENON IMPLIES.

THE PRESENT ARTICLE INTENDS TO BE AN ANALYSIS OF THE CHALLENGES THAT LARGE EUROPEAN CITIES FACE IN MANAGING THE MIGRATION PHENOMENON. IT AIMS AT ANSWERING SOME IMPORTANT QUESTIONS SUCH AS: WHICH ARE THE TOOLS THE CITIES HAVE AT HAND IN ORDER TO DEAL WITH MIGRATION? HOW IS MIGRATION PERCEIVED BY THE INHABITANTS OF THE RECEIVING CITIES? HOW COULD IMMIGRANTS COHABITATE WITH THE LOCALS? WHICH ARE THE POSSIBLE ACTIONS THAT CITIES COULD UNDERTAKE IN ORDER TO FACILITATE THE INTEGRATION OF IMMIGRANTS?

IN THE SAME TIME, ONE AIMS AT ANALYZING THE SOCIAL, CULTURAL, AND NOT LEAST, THE ECONOMIC CHALLENGES THAT EUROPEAN CITIES FACE IN THE MIGRATION PROBLEM.
\end{abstract}

KEYWORDS: IMMIGRANTS, EUROPEAN CITIES, INTEGRATION, SUPPORT, CHALLENGE.

\section{INTRODUCTION}

European Union, this unique economic and political organization ${ }^{2}$, turned out to be a magnet for the immigrants in the last years. With a population of over 446 million inhabitants and a surface of over 4 million $\mathrm{km}^{2^{3}}$, UE is a place with high living standards, political predictability, economic stability, important independent organizations that assure the functioning of democracies in the member states. The rule of law is guaranteed and closely monitored in each member state. Despite the shortcomings of its institutions functioning, one can not deny that the European Union has had a major contribution to maintaining peace on the European continent in the last 50 years.

Peace, political stability, social support, economic development, employment

${ }^{1}$ Collaborator, Dr., Babeș-Bolyai University, mihaelaboc@yahoo.com

${ }^{2}$ https://europa.eu/european-union/about-eu/eu-in-brief_en\#from-economic-to-political-union, Accessed 11 August 2020.

${ }^{3}$ https://europa.eu/european-union/about-eu/figures/living_en , Accessed 11 August 2020. 


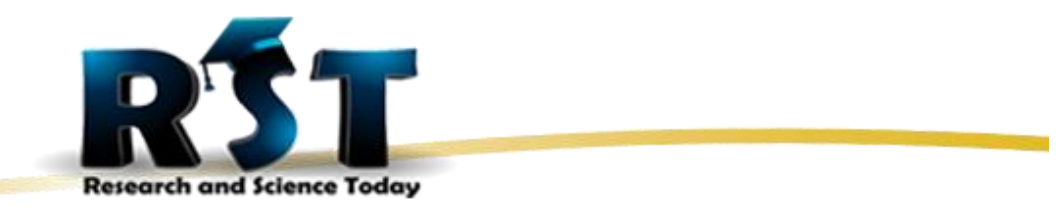

opportunities, these are the main factors that determine people from abroad to choose countries from the European Union as adoptive-homes.

The present article approaches the migration phenomenon focusing on the entities that are the first ones to deal with this issue, that is to say, the hosting cities. Whenever immigrants arrive in a country, the local public administrations must take the first measures to manage the situation. And we refer here especially to the immigration waves and not necessarily to isolate cases. Although there are national legislation and national procedures to be applied in these kinds of situations, the burden of dealing with migration problems falls on the cities.

\section{UNION \\ BEGINNINGS OF MIGRATION PHENOMENON IN THE EUROPEAN}

Migration nowadays has two major causes. On the one hand, people leave their homecountries fleeing the war and therefore migration becomes a humanitarian issue. In this case, immigrants arrive in the host countries usually in big groups, unprepared, deprived of the minimum means of subsistence, and as a consequence urgent help is required.

On the other hand, people leave their home countries looking for a better working place which may ensure them a better living standard. Therefore, in this case, the immigrants are the labor force that the host countries need to carry out certain activities. Immigrants are coming to these countries usually thinking about going back home as soon as they have made enough money to justify their absence.

Another category of migrants is made out of people who decide to leave their homecountries not because they flee the war or because economic conditions oblige them to do so, but because they are seeking for a change, a living place that is more compatible to their personality, better career opportunities or just for simple personal reasons. But this special category is not very numerous and does not raise major issues.

Countries from the European Union have dealt with the migration phenomenon unevenly, in different periods and each of them adopted different measures that were supposed to help them keep under control of this phenomenon. Even though the are under the same umbrella, the EU, each European country has its specificity, particularities, its own cultural issues. Therefore, the migration issue has been approached differently according to the causes that started it, the reasons that determined the choice of that particular country, and the social and political environment of the host country. New political measures were undertaken according to the migration evolution, because migration is related to political development.

The first generation of migrants was formed in France in the 1970 's. 5 . The generation was mostly formed by Maghrebi workers (workers coming from North Africa Marocco, Tunisia, Algerie). In 1974, due to the fact that migration from North Africa was becoming a social issue, the French government established the first Secretariat of State for Immigration. ${ }^{6}$ In the same time, support organizations were established in order to guarantee the immigrants' rights.

1973 was marked by the rise of oile price, the Arab-Israeli war and the economic crise

\footnotetext{
${ }^{4}$ Moses, Jonathon W., Emigration and political development, (New York: Cambridge University Press, 2011), 59.

${ }^{5}$ Brand, Laurie E., Citizens Abroad - Emigration and the State in the Middle East and North Africa, (Cambridge University Press, 2006), 47.

${ }^{6}$ Brand, Laurie E., Citizens Abroad - Emigration and the State in the Middle East and North Africa..., 47.
} 
that followed. In 1977, France introduced a scheme to provide financial inducements to immigrants to return home. At the same time, workers without documents were sent back home which determined hunger strikes. The level of racism also grew up in that period and numerous attacks were noticed against North Africans. ${ }^{7}$

Considering the fact that the number of Maghrebi workers constantly increased ${ }^{8}$, they were perceived by politicians as good voters. Therefore, in 1981, the Socialist Party platform included the proposal to give long-term residents the right to vote for the municipal elections. This proposal faced strong opposition both from French people and from Maroccan and Algerian governments. Invoking the need for constitutional amendments, this issue remained only at the level of the proposal.

In 1981, the restrictions on foreigners' rights of association were lifted and the common right of associations was to be applied to North Americans ever since. This was a major step forward in recognizing fundamental rights to foreigners in France ${ }^{9}$.

As years passed by and the children of the migrants remained in France, a different associative generation has developed, a generation with a different mindset due to its professional and educational background. A generation ready to speak loud for their rights and asking for more and more acceptance. They are not willing to accept the living conditions their grand-parents and parents were forced to. On the other hand, they are still tied in certain ways by their old tradition which makes them difficult to be integrated into France. Therefore, frustration and lack of successful integration often end up in violent conflicts between the state authority and migrants.

To France, immigrants' integration is a very sensitive issue, approached differently by the politicians, according to the electorate they address to, in a nation that cherishes an image of itself as a unified community of citizens, regardless of where they live. ${ }^{10}$

In other European countries, such as Germany, Belgium, or the Netherlands, the North African migration started after the 1960s, as completion or replacer of the Eastern European labor force ( In Italy and Spain even later). Therefore, this wave of migration was seen as a temporary one, no worries for assimilation or integration of the migrant community. ${ }^{11}$

The economic crisis of 1973 affected these countries too, and efforts were made to motivate the workers to go back to their home countries. Despite these efforts, a large number of workers used the liberal family reunification policy that most countries adopted over the years, and so the number of immigrants did not decrease but even grew up. Immigrants' families came with new challenges for European countries. In was not only about labor accords and workers' rights anymore. It was about new socio-political measures, cultural issues, and family integration. ${ }^{12}$ In the Netherlands for example, in order to deal with this

${ }^{7}$ Brand, Laurie E., Citizens Abroad - Emigration and the State in the Middle East and North Africa..., 47

${ }^{8}$ Stephen Castles, Here for Good: Western Europe's New Ethnic Minorities, (London: Pluto Press, 1984), 55.

\begin{tabular}{|l|l|l|l|}
\hline Year & Algerians & Moroccans & Tunisians \\
\hline 1969 & 608000 & 143000 & 89000 \\
\hline 1981 & 817000 & 444,000 & 193000 \\
\hline
\end{tabular}

${ }^{9}$ Brand, Laurie E., Citizens Abroad - Emigration and the State in the Middle East and North Africa, (Cambridge University Press, 2006), 48.

${ }^{10}$ Weinar, Agnieszka, ed. Emigration and Diaspora policies in the Age of Mobility, (Springer international Publishing, European University Institute, Florence, Italy, 2017), 86.

${ }^{11}$ Weinar, Agnieszka, ed. Emigration and Diaspora policies in the Age of Mobility..., 50.

${ }^{12}$ Weinar, Agnieszka, ed. Emigration and Diaspora policies in the Age of Mobility..., 50. 


\section{RST}

matter, in 1984 the Government created a consultative body where representatives of different minorities held seats. The Government needed to consult this body on any question related to minority policy. ${ }^{13}$

In 1985, the long period non-Dutch residents ( five years residence) were given the right to vote in municipal elections. In 1986 they could even run in municipal elections. ${ }^{14}$ The Dutch government also supported the obtaining of Dutch citizenship without renouncing the citizenship of origin. ${ }^{15}$

As far as Germany is concerned, like the other European countries, it tried to encourage workers to go back home following the 1973 economic crisis. Even though the number of workers started to decrease shortly after adopting this policy, the number began to rise in the late 1970s. ${ }^{16}$ Taking advantage of the family reunification policy, the workers, reunited with their families, decided to stay in the adoptive country and so, a new generation was born with complex characteristics.

In 1982, Chancellor Helmut Kohl (right-oriented political coalition) militated for immigration restriction and repatriation. Obtaining German citizenship was not possible without renouncing to the citizenship of origin. This was valid until the year 2000 when German nationality law was changed. ${ }^{17}$

Migration became a very serious issue for Germany starting with Angela Merkel's policy of opening the borders for Syrian refugees in 2015. A large number of persons fleeing war entered the European Union following Angela Merkel's announcement that refugees are welcome to Germany. Around one million refugees arrived in Germany in 2015, this large number raising a series of problems for the German Chancellor. At first, her decision was widely accepted being considered a humanitarian one and being supported by the general wave of emotion that gripped the European population. But as years passed by, the German Chancellor faced numerous critics from the opposition or even from her political coalition regarding the decision she took in 2015. There is no secret that her welcome had in the background the need for a cheap labor force, besides the humanitarian aspect. But the uncomfortable situations that managing this large number of refugees implied, cost her a decrease in popularity and raise her problemes in the following elections.

Nonetheless, countries in the European Union seamed to understand that migration became normality nowadays. Even though migration waves are not that numerous, they still come constantly. Series of procedures and programs have been established at the European level to help countries deal with this phenomenon. Still, each country, each host-city must deal with the specific problems that migrants integration implies. The main challenge they face is to fill in the gap between the "inside" and "outside" 18 world which sometimes is source of racism, social frustration and even violence.

\section{INTEGRATION OF MIGRANTS -EUROPEAN UNION POLICY}

Immigration became a priority to the institutions of the European Union for years now. 89\% of Europe's population growth between 1999 and 2000 is due to immigration. Official statistics show that 4,6 million immigrants are Africans (the real number is estimated

\footnotetext{
${ }^{13}$ Weinar, Agnieszka, ed. Emigration and Diaspora policies in the Age of Mobility ..., 50-51.

${ }^{14}$ Weinar, Agnieszka, ed. Emigration and Diaspora policies in the Age of Mobility..., -51 .

${ }^{15}$ Weinar, Agnieszka, ed. Emigration and Diaspora policies in the Age of Mobility ..., 50-51.

${ }^{16}$ Weinar, Agnieszka, ed. Emigration and Diaspora policies in the Age of Mobility..., 53.

${ }^{17}$ Weinar, Agnieszka, ed. Emigration and Diaspora policies in the Age of Mobility..., 53.

${ }^{18}$ Collyer, Michael, Emigration Nations Policies and Ideologies of Emigrant Engagement, (Palgrave Macmillan, Migration, Diasporas and Citizenship Series, London, 2013), 11.
} 
at around 8 million), that is to say, $30 \%$ of immigrants come from Africa. ${ }^{19}$

The large number of people that migrate from Africa to Europe is justified by economical purposes. Migrants are looking for a safer and better place to live and form a family. Therefore, they come to Europe to stay, and thus the integration issue comes forehead.

At the same time, statistics show that the European population is aging. This causes imbalances in the social-economic system. Working people will have to support the retirement system which becomes a more and more heavy burden. The median age is expected to be 52,3 years old by 2050. On the other hand, 60 percent of Africa's population is under the age of 25 (and the natality rate is at a very high level). This young population, if well integrated, could help European economies stay performant at the international level. ${ }^{20}$

Nonetheless, a recent study of the European Commission shows that migration has a limited effect on changing the EU's age structure. The reason for that is the fact that migrants settle for the long term and they age just as the native population does. ${ }^{21}$ Therefore, demographic aging remains a trend in the EU, despite the young immigrant population that reaches the European territory.

As we have mentioned above, migration is usually caused nowadays by economic factors, by flee from war or political persecution. In the latest case, migrants are asking for asylum, and therefore, if granted, they can benefit from legal protection.

In 2018, 2.4 million people migrated to the EU from non-member countries. These are official figures given by EUROSTAT. At the same time, 3.9 million people immigrated to one of the EU member states and 2.6 million emigrants were reported to have left one of the EU member states. ${ }^{22}$

Next, we will present some official relevant statistics for our study, the source being EUROSTAT. ${ }^{23}$

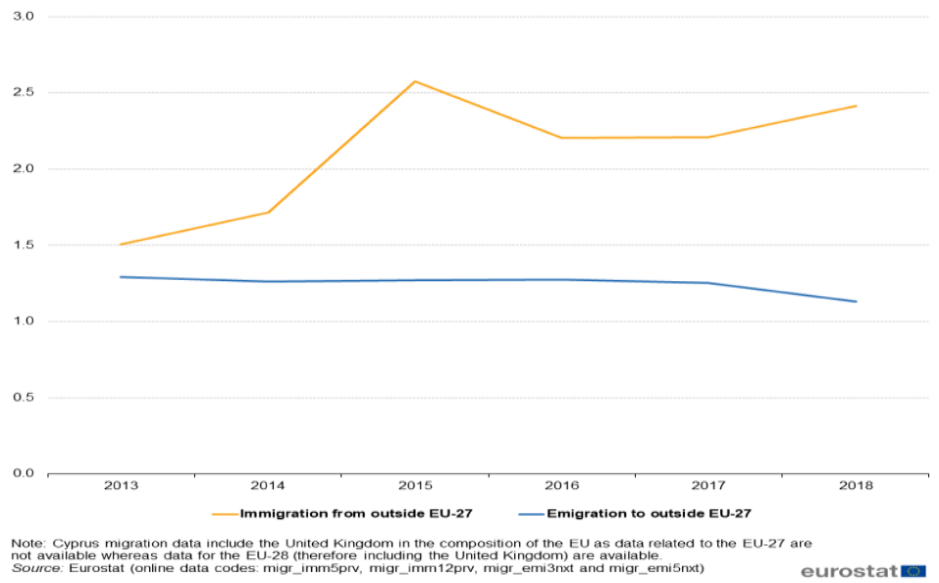

Table 1: Immigrants from outside EU and emigrants to outside EU

\footnotetext{
${ }^{19}$ Mangala, Jack, Africa and its global Diaspora - The policy and politics of Emigration, African Histories and modernities, p.17, https://www.springer.com/series/14758, Accessed 15 August.

${ }^{20}$ Mangala, Jack, Africa and its global Diaspora - The policy and politics of Emigration, African Histories and modernities, p.17, https://www.springer.com/series/14758, Accessed 15 August.

${ }^{21} \mathrm{https} / / / \mathrm{ec}$.europa.eu/jrc/en/publication/eur-scientific-and-technical-research-reports/demographic-scenarios-eu , Accesed 17 August 2020.

${ }^{22} \mathrm{https} / / /$ ec.europa.eu/eurostat/statistics-explained/pdfscache/1275.pdf , Accessed 30 July 2020.

${ }^{23} \mathrm{https}: / /$ ec.europa.eu/eurostat/statistics-explained/pdfscache/1275.pdf , Accessed 17 August 2020.
} 


\section{RST}

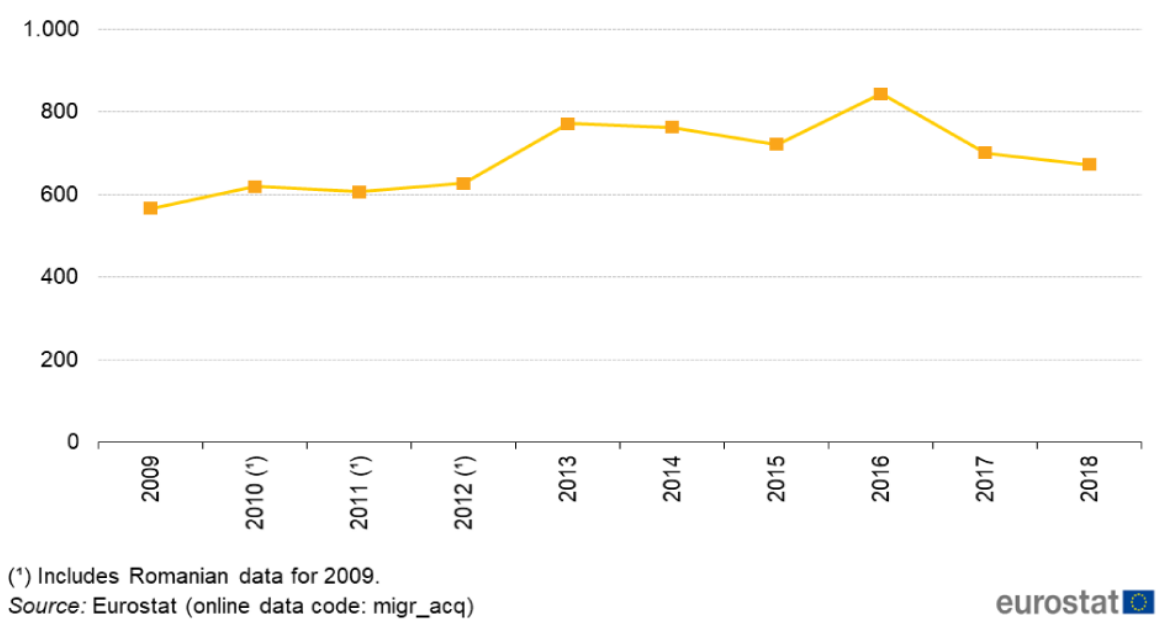

Table 2: Number of persons who acquired the citizenship of an EU member state (2009-2018)

In January 2019, 21.8 million non-EU citizens were living in one of the EU member states. That is to say, $4.9 \%$ of the EU population has the citizenship of a non-member country. Germany is the host for the larger number, 10.1 million persons, followed by Italy (5.3 million), France (4.9 million), and Spain (4.8 million).

On the other hand, 13.3 million persons living in one of the EU member states had the citizenship of another EU member state. ${ }^{24}$

Within the European Union, the member states are primarily responsible for the integration of migrants, including their inclusion in the labor market. Historically, some European states imposed immigrants quota, therefore a previously established number of non-EU persons were accepted in the states, but recently, the general tendency is to introduce some specific criteria that applicants need to fulfill if they want to enter those states, following the model of the European Blue card. Thus, according to the state needs, the criteria refer to education, professional skills, experience in a certain field of activity, etc...

The European Union supports the national and local polices of immigrants' integration with policy coordination, exchange of knowledge, and, of course, financial resources. ${ }^{25}$ Therefore, the Asylum, Migration, and Integration Fund has been created, which finances transnational projects to promote labor market integration. These types of projects can be also financed through the European Social Fund and the Employment and Social Innovation program.

After 2015, the EU significantly increased its funding for migration, asylum and integration polices, and these subjects became a priority on the European agenda. ${ }^{26}$ Workgroups reuniting specialists from all the implied fields of activity, including the civil society, have been created and supported in order to find better solutions and propose

\footnotetext{
${ }^{24} \mathrm{https}: / /$ ec.europa.eu/eurostat/statistics-explained/pdfscache/1275.pdf , Accessed 18 August 2020.

${ }^{25} \mathrm{https} / / /$ ec.europa.eu/home-affairs/what-we-do/policies/legal-migration/integration_en, Accessed 16 August 2020.

${ }^{26} \mathrm{https} / / / \mathrm{www}$.bruegel.org/2018/05/eu-funds-for-migration-asylum-and-integration-policies/, Accessed 30 July 2020.
} 
legislative modifications to help dealing with this phenomenon.

The EU law imposes some specific obligations to the member states as refer to immigrants. The Reception Conditions Directive (2013/33/EU) ${ }^{27}$ refers to the member states' obligation to provide asylum seekers decent reception conditions (housing, food, clothing, or a daily allowance and access to health care, psychological care, and employment. At the same time, in some specific, exceptional cases, the member states have the right to reduce or even withdraw all these material conditions (Art.20). Applicants for international protection have the right to enter the labor market, at the latest nine months after lodging their application (Article 15(1)). Still, the member states have the right to restrict access for reasons of labor market policy and give priority to Union citizens and EEA nationals, as well as legally resident third-country nationals (Article 15(2)).

Qualification Directive $(2011 / 95 / \mathrm{EU})^{28}$ provides the member states' obligation to ensure access to integration facilities. The member states, considering the specific profile and needs of beneficiaries of refugee status or of subsidiary protection status, must establish integration programs in order to simplify the accommodation of beneficiaries with the new state and to integrate into the society.

In order to support member states in their effort of elaborating viable integration policies, on 7 June 2016, the European Commission adopted an Action Plan on the integration of third-country nationals. This action plan describes in detail the measures that the European Commission will implement in this matter. Even though this Action plan refers to third-country nationals in the EU, it also contains actions to undertake within the challenges the refugees need to face.

As we have mentioned above, the European Union has established the framework for the migrants' integrations, but the responsibility belongs to member states. The European directives are transposed into the national legislation and so, each member state establishes specific actions and programs to be applied in order to facilitate the migrants' integration.

There are four types of migrants that come to the EU: labor migrants, demanders for asylum, beneficiaries of family integration programs, and seasonal workers. Migration within the member states is relatively more simply to be managed by the European institutions and that is because there are a series of common rights that the European citizens have and these rights are guaranteed by the European law, which each member state needs to respect.

Moreover, each state is politically represented at all levels within the European institutions, and therefore, having a common background and common political and law institutions, things are much simpler to manage. Things get a little bit more complicated when we talk about third-country migrants.

In these cases, besides the economic and social aspects, we also must deal with significant cultural differences which sometimes are very difficult to overcome. Labor migrants don't necessarily want to settle for good in the host country, and that is partly why they regard their stay as a temporary status and do not want to be integrated into the new community, but want to remain loyal to their old culture and traditions. People from the hostcommunities sometimes are reticent in letting someone new to disturb their way of living and here come the integration challenges.

In order to simplify migration procedures, in December 2011 was adopted the Single Permit Directive, which gives the non-EU workers legally residing in an EU state some important rights, out of which, the right to equal treatment with nationals in the country they

\footnotetext{
${ }^{27} \mathrm{https}$ ///eur-lex.europa.eu/legal-content/EN/TXT/?uri=celex\%3A32013L0033, Accessed 17 August 2020.

${ }^{28} \mathrm{https}: / /$ eur-lex.europa.eu/legal-content/EN/TXT/?uri=celex\%3A32011L0095, Accessed 17 August 2020.
} 


\section{RST}

work and reside. ${ }^{29}$ This Directive is applicable to the majority of the non-EU workers who have the authorization to reside and work in the EU, ignoring the initial reason for accessing the UE territory. Therefore, this Directive refers to a single permit for residence and work, a single application procedure for the permit, and a series of rights such as working conditions, freedom of associations, education, recognition of diploma, tax benefits, social security, etc... ${ }^{30}$

- Family reunification seems to be the main reason for immigration in the last 20 years. $^{31}$ Family reunification is the right given to the legal immigrant (the sponsor) to be reunited by his family. The Directive on the right to family reunification is applicable to 25 out of 27 member states (Ireland and Denmark are excepted) and includes a series of common procedures to be followed by family reunification seeker. The legal immigrant can be joined by his spouse, minor children and the children of their spouse. The reunification with an unmarried partner, adult dependent children, or dependent parents and grandparents could be allowed by the member states. After receiving the residence permit, the family members get access to education, labor force, and vocational training. ${ }^{32}$

Member states have the right to establish some special admission conditions such as for the sponsor to have good accommodation conditions, health insurance, financial resource, and they can impose a waiting period of no more than two years. Polygamy is not accepted.

For the refugees, taking into account their special situation, the family reunification conditions are simplified..$^{33}$

The EU gives the possibility to long-term residents to receive the EU long-term permit as a consequence of the good behavior they had within the community for an uninterrupted period of five years. ${ }^{34}$ Therefore, in 2003, the Directive on the status of non-EU nationals who are long-term residents has been adopted. This long-term residence permit can be received if the applicant fulfills some conditions such as having a stable financial situation and regular income, health insurance, not being a threat to public security and public policy, following some integration measures (if required by the member state). ${ }^{35}$

The long-term permit, which is renewable, gives the owner the possibility to enjoy certain rights as the EU citizens such as access to employment, education and vocational training, social protection, etc... ${ }^{36}$

The European Union makes constant efforts in order to stop migrant smuggling. ${ }^{37}$

\footnotetext{
${ }^{29} \mathrm{https} / / /$ ec.europa.eu/home-affairs/what-we-do/policies/legal-migration/work_en, Accessed 17 August 2020.

${ }^{30}$ https://ec.europa.eu/home-affairs/what-we-do/policies/legal-migration/work_en , Accessed 17 August 2020.

${ }^{31}$ https://ec.europa.eu/home-affairs/what-we-do/policies/legal-migration/family-reunification_en, Accessed 17 August 2020.

${ }^{32}$ https://ec.europa.eu/home-affairs/what-we-do/policies/legal-migration/family-reunification_en, Accessed 17 August 2020.

${ }^{33}$ https://ec.europa.eu/home-affairs/what-we-do/policies/legal-migration/family-reunification_en, Accessed 17 August 2020.

${ }^{34}$ https://ec.europa.eu/home-affairs/what-we-do/policies/legal-migration/long-term-residents_en, Accessed 18 August 2020.

${ }^{35} \mathrm{https} / / /$ ec.europa.eu/home-affairs/what-we-do/policies/legal-migration/long-term-residents_en, Accessed 18 August 2020.

${ }^{36}$ https://ec.europa.eu/home-affairs/what-we-do/policies/legal-migration/long-term-residents_en, Accessed 18 August 2020.

${ }^{37}$ https://ec.europa.eu/home-affairs/what-we-do/policies/irregular-migration-return-policy_en, Accessed August 2020.
} 
Desperate people, fleeing war or hunger, contact criminal networks of smugglers that sell them the chance to enter the EU. Images showing numerous boats with hundreds of people crossing the Mediterranean Sea trying to rich the EU territory were very common and raised international compassion especially in 2015-2016. These criminal networks put people's lives in great danger for a very large amount of money. They are well connected to criminal networks within the EU territory which sometimes could offer counterfeit legal documents.

These illegal migrants are very fragile and often subject to labor exploitation and trafficking in human beings.

In order to discourage the migrant smuggling, the EU had made some significant improvements within its legislation, strengthened the external borders, and the cooperation between surveillance authorities. ${ }^{38}$

Despite all the efforts that the European Union undertakes in order to deal with the migration phenomenon, this remains a very sensitive subject. Rather we talk about the migration within the member states or about the migration from non-EU countries, this phenomenon comes with a series of challenges that are not all the time easy to deal with. According to the social-economic situation of a particular state, migration is often used as a political issue especially by right-oriented political parties, which determine an increase in frustration that eventually leads to social tensions, often reorientation of national policies or even acts of violence. Migration and its negative effect on the national economy was one of the favorite subjects of Brexit militants, raising many debates and frictions at the European level during Brexit negotiations.

Nonetheless, it is largely accepted within the European Union that migrants contribute to the development of their host society, rather we talk about economic, social, or cultural development. ${ }^{39}$ It all depends on how the integration process succeeds.

\section{LEVEL}

INTEGRATION OF MIGRANTS - ACTIONS TAKEN AT THE CITIES

Integration is defined by the EU member states in their internal legislation, but the common ground for defining integration is the principle of a dynamic, two-way process of mutual accommodation. ${ }^{40}$

From their experience, the member states noticed that the main integration challenges are connected to the difficulty in accessing the labor market, especially for women. The problematic issues are lack of language knowledge, lack of recognition of qualification or the need to accept a job that does not match the qualification or the skills of the applicant, and discriminatory practices applied by the employers. ${ }^{41}$

Statistics show that the unemployment rate for people born outside the EU but EU residents is higher in the large majority of the EU countries. In the same time, as far as the risk of poverty or social exclusion is concerned, $21 \%$ of nationals, $29 \%$ of foreign EU citizens and $45 \%$ of non-EU citizens living in the EU faced the risk of poverty or social

\footnotetext{
${ }^{38} \mathrm{https} / / /$ ec.europa.eu/home-affairs/what-we-do/policies/irregular-migration-return-policy_en, Accessed 17 August 2020.

${ }^{39} \mathrm{https} / / /$ ec.europa.eu/home-affairs/what-we-do/policies/legal-migration/integration_en, Accessed 17 August 2020 .

${ }^{40} \mathrm{https} / / /$ ec.europa.eu/home-affairs/sites/homeaffairs/files/00_eu_labour_market_integration_final_en.pdf, Accessed 1 August 2020.

${ }^{41}$ https://ec.europa.eu/home-affairs/sites/homeaffairs/files/00_eu_labour_market_integration_final_en.pdf, Accessed 1 August 2020.
} 


\section{RST}

exclusion in $2018 .^{42}$

\begin{tabular}{|l|l|l|l|}
\hline $\begin{array}{l}2019 \quad \text { EU }(27 \\
\text { member states) } 43\end{array}$ & $\begin{array}{l}\text { For those born outside } \\
\text { the EU }\end{array}$ & $\begin{array}{l}\text { For the native-born } \\
\text { population }\end{array}$ & $\begin{array}{l}\text { For those born in another EU } \\
\text { Member State }\end{array}$ \\
\hline $\begin{array}{l}\text { Employment rate } \\
\text { for people aged } 20 \\
\text { to 64 years }\end{array}$ & $64.4 \%$ & $73.9 \%$ & $75.3 \%$ \\
\hline $\begin{array}{l}\text { Unemployment rate } \\
\text { for people aged } 20 \\
\text { to 64 years }\end{array}$ & $12.3 \%$ & $6.0 \%$ & $7.3 \%$ \\
\hline
\end{tabular}

Figure 1

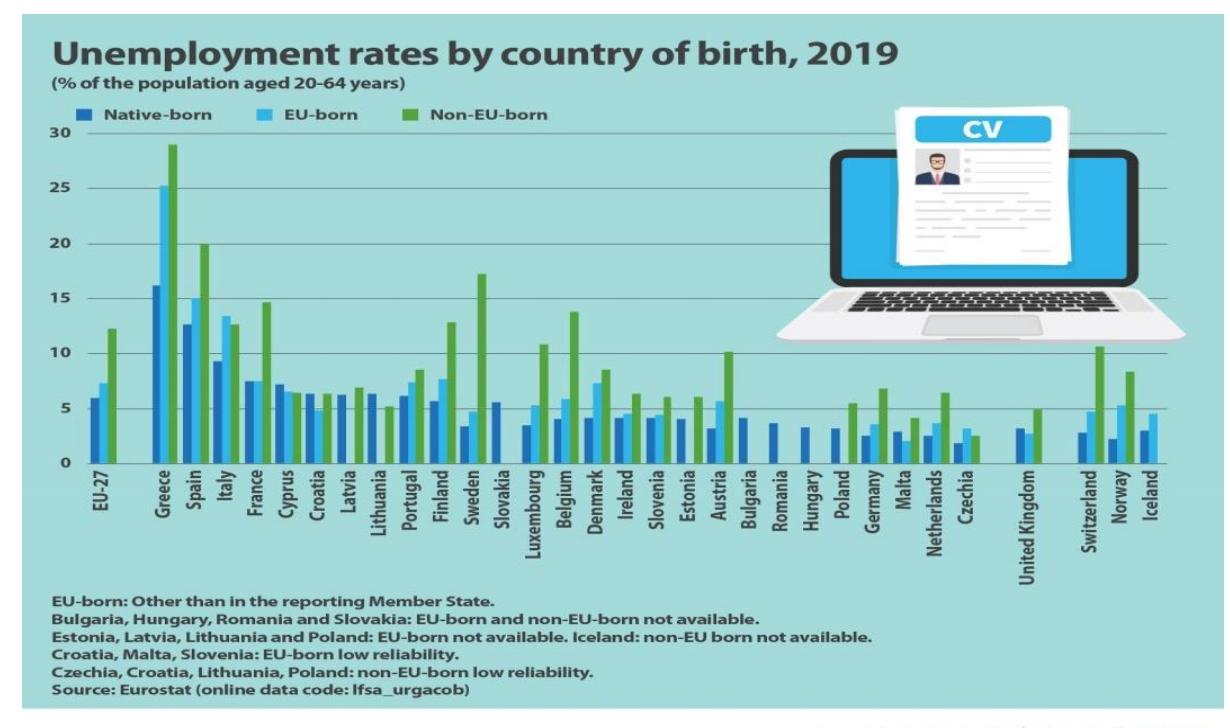

ec.europa.eu/eurostat

Table 3

Migrant integration is a responsibility assumed at the national level, but in some cases, national authorities devolve some integration responsibilities to local authorities or subnational authorities. ${ }^{44}$

In the end, local and regional authorities are the ones to deal directly with migrants, and therefore, they need to properly handle the support they take from the national and European level.

The main challenge the integration process supposes is the access to the labor market. Once the migrants defined their legal residence papers, they need to start supporting themselves. Sometimes, finding a job is not a very easy task to do. And the local authorities need to help them with this matter.

Finding a job is not the final chapter of the integration process. Integration also

\footnotetext{
${ }^{42}$ https://ec.europa.eu/eurostat/statistics-explained/index.php?title=Migrant_integration_statistics_at_risk_of_poverty_and_social_exclusion, Accessed 18 August 2020.

${ }^{43} \mathrm{https}: / /$ ec.europa.eu/eurostat/statisticsexplained/index.php?title=Migrant_integration_statistics_\%E2\%80\%93_ labour_market_indicators, Accessed 18 August 2020.

${ }^{44}$ file:///C:/Users/840G3/Downloads/MPIE_UrbanAgenda_LabourMarketIntegration-FINAL.pdf, Accessed 3 August 2020.
} 
implies social aspects, cultural and educational aspects.

We present below some actions undertaken by several European cities that deal with migration, presented in a rapport of the Eurocities on Labor market integration of refugees and asylum seekers from December 2017. ${ }^{45}$

The above-mentioned report shows that regarding the integration of refugees in the labor market, cities such as Enschede, Lisbon, Milan, Ostend, Riga, and Tampere have direct responsibility, while Berlin, Dortmund, Munich, Nantes, Nuremberg, Stuttgart share responsibility with regional, federal or national governments.

Employment agencies, job centers, and the ministries for labor and social affairs are responsible. Munich, for example, has established a consultancy service for migrants in order to match the workers skills with the needs of local businesses.

Some European cities don't have a direct responsibility in migrant integration, but they assume an indirect, voluntary one. Barcelona and Ghent, for example, support complementary services, structures, or programs to complete the national ones.

Gothenburg, Malmo, and Stockholm cooperate with the state, which has direct responsibility through the Swedish public employment service, by providing support such as language courses, housing, etc.

As far as policymaking is concerned, some cities share this responsibility with job centers and the city's economic affairs, education, culture, and sports departments (Berlin, Dortmund, Enschede, Nuremberg, Riga, and Tampere). Others cooperate with social care services providers (Barcelona, Gothenburg, Malmo, Munich, Ostend, Stockholm, and Stuttgart). Some cities have dedicated structures for working on migration and refugees (Barcelona, Vienna, Milan, Lisbon).

Usually, most European cities, to address access to the labor market for the migrants, cooperate with different structures that might help in this endeavor.

Rather we talk about internal cooperation (interdepartmental cooperation within public authorities, usually under the coordination of the social affairs and integration department Barcelona, Berlin, Dortmund, Enschede, Lisbon, Nuremberg, and Tampere - or cooperation with stakeholders (cooperation with private companies, social services, employment agencies, foundations, and other social and economic organizations), and NGOs (Barcelona, Berlin, Dortmund, Ghent, Gothenburg, Lisbon, Milan, Munich, Ostend, Nuremberg, Riga, Stockholm, Vienna), integration of migrants supposes a holistic approach, not only concerning access to the labor force. We refer here to health care, housing, language skills, psychological assistance. And this approach, due to its complexity, requires strong cooperation with institutions, public and private, from the regional and national levels, which is often formalized into formal agreements.

The big number of refugees and asylum seekers found some cities public administrations unprepared and they encountered big difficulties in dealing with this new situation. Therefore, cities like Enschede and Tampere hired new personnel to deal with integration into the labor market of refugees.

Cities also reported legislative issues regarding the difficulty of obtaining a residence permit and the diploma/skills recognition to be able to access the labor market (Berlin, Dortmund, Nuremberg, and Stuttgart). Therefore, they worked with the national authorities to promote laws that respond to the actual needs.

The Eurocities study that we refer to mention some measures undertaken at the local

\footnotetext{
${ }^{45} \mathrm{http} / / /$ nws.eurocities.eu/MediaShell/media/Labour_market_integration_of_refugees_and_asylum_seekers.pdf, Accessed 5 August 2020.
} 


\section{RST}

level by the cities to facilitate access for the migrants to the labor market. Out of these measures, we remind here the most important ones:

- free language courses (Berlin, Dortmund, Ghent, Gothenburg, Nuremberg, Malmo, Milan, Munich, Stockholm, Stuttgart, Tampere and Vienna, Malmo)

- motivational and counseling programs, information group activities (Berlin, Ghent, Malmo, Munich, Vienna)

- vocational training, education for skills development (Berlin, Milan)

- job-matching services (Barcelona, Berlin, Dortmund, Ghent, Gothenburg, Malmo, Milan, Munich, Nuremberg, Stockholm, Stuttgart, and Tampere).

- social clauses in public procurement (Barcelona)- clauses that encourage business that win public contracts to hire asylum seekers or refugees

The above-mentioned services for the migrants are free and provided in different languages. As far as the money is concerned, it comes from the city, national, federal, and EU level (European Social Fund, e Asylum, Migration and Integration Fund) or public-private sponsorship.

\section{MIGRATION ISSUE IN ROMANIA}

Romania became a member of the EU in 2007. Every since, it adopted into its national legislation the community acquis and the legislation regarding immigrants do not make an exception. The national main normative acts that refer to migrants are the Emergency Ordinance no. 194/2002 regarding the aliens' regime, the Law no. 122/2006 regarding the Asylum in Romania and the Ordinance no.44/2004 on the social integration of foreigners who have acquired a form of protection in Romania.

Romania is one of the European countries with the highest percentage of emigrants, one estimating that if this trend continues, by 2060 the Romanian population will decrease to around 12 million inhabitants.

The high level of emigration determined a lack of working force in Romania, which determines the entrepreneurs to seek workers in non-EU countries.

Romania is traditionally considered to be a friendly country for foreigners. Due to the fact that in the last 25 years Romanian citizens had the chance to travel much more easily abroad and with the change in generations, Romanians became more open-minded. Still, especially in rural or less developed areas, one can still find racism and intolerance towards foreigners. A recent example was the case of a bakery in Ditrău, Harghita county, where hundreds of locals protested against hiring workers from Sri Lanka. Local authorities tried to settle the conflict and the large national opinion was supportive to Sri Lanka workers.

In order to have a general overview of the situation of migrants in Romania, we have addressed a request to the General Inspectorate for immigration and by the response to our address no.347866, they have communicated us the following statistics:

\begin{tabular}{|c|c|c|c|c|c|c|c|}
\hline \multicolumn{8}{|c|}{ Figure 2: Illegal Migrants } \\
\hline $\begin{array}{l}\text { State of } \\
\text { origin }\end{array}$ & $\begin{array}{l}201 \\
5\end{array}$ & 2016 & 2017 & 2018 & 2019 & 30.04 .2020 & Total \\
\hline IRAK & 71 & 256 & 1012 & 202 & 78 & 27 & 1646 \\
\hline SYRIA & 154 & 125 & 205 & 41 & 39 & 123 & 687 \\
\hline $\begin{array}{l}\text { AFGANISTA } \\
\mathrm{N}\end{array}$ & 61 & 73 & 50 & 25 & 71 & 39 & 319 \\
\hline PAKISTAN & 17 & 103 & 83 & 30 & 17 & 2 & 252 \\
\hline
\end{tabular}


Autumn 2020

No. $2(20) / 2020$

ISSN-P: 2247-4455 / ISSN-E: 2285-9632

\begin{tabular}{|l|l|l|l|l|l|l|l|} 
IRAN & 24 & 25 & 117 & 44 & 29 & 4 & 243 \\
\hline OTHER & 107 & 238 & 184 & 164 & 160 & 155 & 1008 \\
\hline TOTAL & 434 & 820 & 1651 & 506 & 394 & 350 & 415 \\
\hline
\end{tabular}

\begin{tabular}{|c|c|c|c|c|c|c|c|}
\hline \multicolumn{8}{|c|}{ Figure 3: Asylum applications } \\
\hline State of origin & 2015 & 2016 & 2017 & 2018 & 2019 & B0.04.2020 & Total \\
\hline IRAK & 117 & 292 & 2589 & 970 & 622 & 111 & 4701 \\
\hline SYRIA & 228 & 182 & 494 & 87 & 153 & 269 & 1413 \\
\hline $\begin{array}{l}\text { AFGANISTA } \\
\mathrm{N}\end{array}$ & 90 & 66 & 240 & 43 & 174 & 133 & 746 \\
\hline IRAN & 22 & 17 & 198 & 160 & 116 & 2 & 515 \\
\hline PAKISTAN & 20 & 82 & 231 & 29 & 32 & 4 & 398 \\
\hline OTHER & 102 & 157 & 258 & 263 & 724 & 422 & 1926 \\
\hline TOTAL & 579 & 796 & 4010 & 1552 & 1821 & 941 & 9699 \\
\hline
\end{tabular}

\begin{tabular}{|l|l|c|l|l|l|l|}
\hline State of origin & 2015 & 2016 & 2017 & 2018 & 2019 & 30.04 .2020 \\
\hline MOLDAVIA & 9272 & 10485 & 10313 & 9990 & 11920 & 13101 \\
\hline TURKEY & 8882 & 9087 & 9317 & 9235 & 10458 & 10564 \\
\hline CHINA & 7542 & 7728 & 7894 & 7894 & 8391 & 8380 \\
\hline VIETNAM & 820 & 790 & 1150 & 3026 & 5447 & 5623 \\
\hline SYRIA & 4505 & 4852 & 5282 & 5255 & 5252 & 5204 \\
\hline & 2923 & & & & & \\
OTHER & 6 & 31955 & 33179 & 33782 & 40878 & 44372 \\
\hline & 6025 & & & & & \\
TOTAL & 7 & 64897 & 67135 & 69182 & 82346 & 87244 \\
\hline
\end{tabular}

Figure 4: Migrants with a residence permit

\begin{tabular}{|l|l|l|l|l|l|l|l|}
\hline $\begin{array}{l}\text { State } \\
\text { origin }\end{array}$ & 2015 & 2016 & 2017 & 2018 & 2019 & 30.04 .2020 & Total \\
\hline VIETNAM & 18 & 51 & 624 & 2508 & 3797 & 586 & 7584 \\
\hline TURKEY & 270 & 289 & 425 & 644 & 1796 & 612 & 4036 \\
\hline SRI LANKA & 85 & 124 & 199 & 415 & 1832 & 570 & 3225 \\
\hline NEPAL & 4 & 49 & 136 & 411 & 1707 & 860 & 3167 \\
\hline CHINA & 332 & 374 & 491 & 529 & 1072 & 169 & 2967 \\
\hline OTHER & 915 & 833 & 1088 & 1860 & 6152 & 2431 & 13279 \\
\hline TOTAL & 1624 & 1720 & 2963 & 6367 & 16356 & 5228 & 34258 \\
\hline
\end{tabular}

Figure 5: Working permit

As the above figures show, migration doesn't raise, at present, major problems for Romania. But if emigration continues in such a large proportion, the Romanian entrepreneurs will need to seek more and more workforce into the non-EU countries. 


\section{RST}

\section{CONCLUSION}

Migration is a continuous phenomenon that comes with significant challenges for the countries involved. Rather we talk about refugees, temporary workers, or asylum seekers, in the end, the purpose remains the integration of the migrants into the host communities. Failure to do so gives birth to frustrations, poverty, acts of violence, and thus disturbs the equilibrium and the well-being of the community.

Our analysis showed that EU countries take similar actions while dealing with integration, being all of them under the umbrella of the European legislation.

Nevertheless, the European cities develop pilot programs for the integration of migrants, according to the specific problems they encounter. Sharing experiences and working together to find improved solutions to this phenomenon could end up in better integration.

Thus, what we consider the cities need to do is not only to work on the integration of migrants but also to work on acceptance by the locals. The key to finding an equilibrium in their community is, apart from financial resources that integration requires, education on both sides, equal rights and opportunities, tolerance, and social participatory programs. It is essential to learn to accept and respect the differences in behavior, culture, or mentality but the respect needs to be mutual. 


\section{REFERENCES}

\section{Books}

1. Castles, Stephen, Here for Good: Western Europe's New Ethnic Minorities, Pluto Press, London, 1984.

2. Brand, Laurie E., Citizens Abroad - Emigration and the State in the Middle East and North Africa, Cambridge University Press, 2006.

3. Weinar, Agnieszka, Emigration and Diaspora policies in the Age of Mobility, Springer international Publishing, European University Institute, Florence, Italy, 2017.

4. Mangala, Jack, Africa and its global Diaspora - The policy and politics of Emigration, African Histories and modernities, https://www.springer.com/series/14758.

5. Collyer, Michael, Emigration Nations Policies and Ideologies of Emigrant Engagement, Palgrave Macmillan, Migration, Diasporas and Citizenship Series, London, 2013.

6. Moses, Jonathon W., Emigration and political development, Cambridge University Press, https://www.cambridge.org/core/books/emigration-and-political development.

\section{Internet sources}

1. Mangala, Jack, Editor, Africa and its global diaspora - The policy and politics of Emigration, African Histories and modernities, https://www.springer.com/series/14758.

2. https://ec.europa.eu/jrc/en/publication/eur-scientific-and-technical-research reports/demographicscenarios-eu.

3. https://eur-lex.europa.eu/legal-content/EN/TXT/?uri=celex\%3A32013L0033.

4. https://eur-lex.europa.eu/legal-content/EN/TXT/?uri=celex\%3A32011L0095.

5. https://ec.europa.eu/home-affairs/what-we-do/policies/legal-migration/integration_en.

6. https://ec.europa.eu/home-affairs/what-we-do/policies/legal-migration/work_en.

7. https://ec.europa.eu/home-affairs/what-we-do/policies/legal-migration/family-reunification_en.

8. https://ec.europa.eu/home-affairs/what-we-do/policies/legal-migration/long-term-residents_en.

9. https://europa.eu/european-union/about-eu

10. https://ec.europa.eu/home-affairs/what-we-do/policies/irregular-migration-return-policy_en.

11. https://ec.europa.eu/eurostat/statisticsexplained/index.php?title=Migrant_integration_statistics_\%E2\%80\%93 labour_market_indicators

12. https://www.oecd-ilibrary.org/docserver/9789264307216en.pdf?expires $=1597786549 \& \mathrm{id}=\mathrm{id} \&$ accname $=$ guest $\&$ checksum $=4$ FC7788D1D93BBDAA0AA90931 B159626.

13. https://www.bruegel.org/2018/05/eu-funds-for-migration-asylum-and-integration-policies/

14. file:///C:/Users/840G3/Downloads/MPIE_UrbanAgenda_LabourMarketIntegration-FINAL.pdf.

15. http://nws.eurocities.eu/MediaShell/media/Labour_market_integration_of_refugees_and_asylum_seeke rs.pdf.

16. https://ec.europa.eu/eurostat/statistics-explained/pdfscache/1275.pdf. 